\title{
DIRECTIONS FOR IMPROVING OF THE LABOR MOTIVA- TIONAL SYSTEM THROUGHT ANALYSIS OF WORKERS' MOTIVES AND NEEDS AT THE NATIONAL ENTERPRISES
}

\author{
Tetiana Kulynych ${ }^{1}$, Inna Rudenko ${ }^{2}$, Nataliia Postolna ${ }^{3}$, Olena Holovanova ${ }^{4}$, Iryna Torianik ${ }^{5}$, \\ Olena Vnukovska-Mistal ${ }^{6}$
}

\author{
${ }^{1}$ Department of economics, management and administration, Kharkiv College of Trade and Economics Kyiv National University of Trade \\ and Economics, Kharkiv, Ukraine \\ 163.kulinich@gmail.com \\ ORCID: http://orcid.org/0000-0002-6997-0537 \\ ${ }^{2}$ Department of economics, management and administration, Kharkiv College of Trade and Economics Kyiv National University of Trade \\ and Economics, Kharkiv, Ukraine \\ innazin1791@gmail.com \\ ORCID: http://orcid.org/0000-0001-5940-2344 \\ ${ }^{3}$ Department of economics, management and administration, Kharkiv College of Trade and Economics Kyiv National University of Trade \\ and Economics, Kharkiv, Ukraine \\ ya.nataliya.postolnaya@gmail.com \\ ORCID: http://orcid.org/0000-0002-7283-5870 \\ ${ }^{4}$ Department of economics, management and administration, Kharkiv College of Trade and Economics Kyiv National University of Trade \\ and Economics, Kharkiv, Ukraine \\ ivanovaelena0912@gmail.com \\ ORCID: http://orcid.org/0000-0001-5409-9016 \\ ${ }^{5}$ Department of tourism and socio-humanitarian disciplines, Kharkiv College of Trade and Economics Kyiv National University of Trade \\ and Economics, Kharkiv, Ukraine \\ toryanik.ira09@gmail.com \\ ORCID: http://orcid.org/0000-0002-2169-748X \\ ${ }^{6}$ Cultural and educational centre «Castle Arts», Bagnoles de L'Orne, France \\ chateaudesarts@gmail.com \\ ORCID: http://orcid.org/0000-0003-2390-4574
}

ARTICLE INFO

Article history:

Received date 07.05 .2020

Accepted date 15.06.2020

Published date 30.06 .2020

Section:

Communication Studies

D O I

$10.21303 / 2313-8416.2020 .001337$

KEYWORDS

job satisfaction

value orientations

needs

motives

work motivation

work organization
ABSTRACT

Object of research: the article presents the results of a study conducted by the authors by interviewing employees of industrial enterprises on such important issues as satisfaction with the level of work organization, work performed, motives of job attractiveness, equipment of workplaces, job satisfaction and wages, work motives and the relationship of wages with the final results of work.

Solved problem: increasing the level of work motivation by creating motives for attractiveness, job satisfaction and wages of workers at industrial enterprises of Ukraine. Main scientific results: a close connection between value orientations and motives of human activity is proved. The need to improve the system of labor motivation at enterprises, increase employee satisfaction with their work by optimizing the level of wages, creating optimal working conditions, sufficient equipment of workplaces. The existing organization of work does not fully correspond to the manifestation of the abilities of employees and work with full efficiency, only with rare exceptions, most respondents said they were satisfied with the work performed.

Scope of practical use of research results: research results can be used for increase of level of motivation of work of workers, perfection of the organization of work, creation of motives of attractiveness, increase of satisfaction with the work and wages of workers at the industrial enterprises of Ukraine. All measures to improve the organization of labor should be primarily aimed at increasing social and creative activity, independence in work. In a market economy, it is not enough just to follow their job descriptions, without initiative and independence. Therefore, the requirements for employees and their qualities are growing.

(C) The Author(s) 2020. This is an open access article under the CC BY license http://creativecommons.org/licenses/by/4.0).

\section{Introduction}

\section{1. Object of research}

The article is devoted to the problem of increasing the level of workers motivation, analysis and identification of the influence of the level of labor organization on satisfaction with their labor and wages of workers at industrial enterprises of Ukraine. 


\section{2. Description of the problem}

The need to increase the level of work motivation among the employees of enterprises as one of the main conditions for increasing production efficiency has long been understood by both owners of capital and government in countries with advanced market economies. It is necessary to constantly increase workers' interest to the efficient work, so that they feel like true masters of production. Such interest is born only when there is a direct connection between the results of work and its remuneration. The motivation for choosing a particular course of action depends on the value orientation of the person. Orientation of value orientations determines the needs, their subordination and role in the consciousness of the individual. "The value orientations of an agent or group of people are a system of values, with an assessment of their importance, which determines the orientation of human behavior" [1, p. 115].

Modern theories of work motivation pay much attention to the definition, structure and list of needs. Social needs are divided into two main groups: the needs of society and the population (personal needs). The motivation of human labor is directly influenced by personal needs, which are strong, manage the labour motivation that is tend to meeting needs. When workers activity is wise and multidimensional his/her needs are more diverse, because of this the more important is the study, understanding of the internal mechanisms of work motivation [2].

\section{3. Supposed way of problem decision}

Motives and needs of work activity create labor values. "Labor value is a motivationally significant aspect and it is the least integral element of the motivational sphere" [3]. Many published works are devoted to the study of labor values. For example, study of workers values conducted by Ukrainian researchers Hayet G. and Eskov O., allowed to distinguish the main labor motivational types of modern workers: "master altruist", "commander-collectivist" and "self-lover" [1, p. 170]. The researches were conducted in order to analyze the degree of significance and satisfaction of values, which allowed to determine directions of improvement of the work system among workers. Further studies of workers values allowed to determine the influence degree of individual methods on workers motivation, to develop a model of their motivational structure and motivational portrait [4].

Nowadays, according to studies of Ukrainian scientists [5-7], workers are primarily interested in work values related to material well-being. Motivation that is based on earnings pays attention on the distribution and redistribution of what has already been created but unfortunately incentives such as production increasement aren't included. Popularization of basic values (wages) has appeared because of crisis phenomenon in the field of work, external factors that put the employee before the alternative of choosing between work itself and the wage level. The motivation of work is not deformed by the peculiarities of consciousness but by the system of labor management. The logical conclusion of this process is that interest in the work itself at the level of practical consciousness has ceased to be a meaningful motive for work and has replaced the motive of "duty" [8].

Changes in basic motive "wage" for "well-being" is fully in line with current realities and refers to economic means of motivation. In addition to wages, economic incentives include bonuses, cash benefits, financial aid, loans, participation in income, and etc.

Foreign researchers also define material remuneration as an employee's incentive to high-productivity work [9], in addition, proved the necessity of conducting a business evaluation of staff in order to enhance work motivation [10], a theoretical approach has been developed to enhance the employee's incentive to achieve the organization's goals [11], a human behavioral model for service productivity has been proposed [12].

The actual phases in the preparation, creation, and realization/implementation of the motivational programme can be broken down into the following basic steps (Fig. 1).

Imperfection of modern systems which are already exist at the enterprises deals with uncertainty of work values, motives of attractiveness, satisfaction with the organization of work, etc.

The aim of the study is to try to identify the shortcomings in the organization of work in domestic enterprises, to emphasize the need for continuous questioning of employees about their motives and needs, which will significantly improve the system of motivation at work. 


\begin{tabular}{|c|c|c|c|c|c|}
\hline $\begin{array}{l}\text { Enterprise } \\
\text { Motivator }\end{array}$ & $\begin{array}{l}\text { Motivator/ } \\
\text { Employee }\end{array}$ & $\begin{array}{l}\text { Employee } \\
=\text { Cluster }\end{array}$ & $\begin{array}{l}\text { Motivational } \\
\text { Programme }\end{array}$ & $\begin{array}{c}\text { Practical } \\
\text { Verification }\end{array}$ & $\begin{array}{l}\text { Motivational } \\
\text { Programme }\end{array}$ \\
\hline Analvsis & Clusters & Analvsis & Creation & & Implementation \\
\hline
\end{tabular}

Fig. 1. Schema of the creation of motivational programmes using the cluster analysis [13]

\section{Materials and methods}

There is a close link between value orientations and motives of human activity. The internal choice of one or another act, its motivation, largely depend on value orientations that are common to people. Conscious attitude to work, for example, is difficult to bring up in an employee with a poorly expressed value orientation to work. Those who consider work to be the most important personal and social value, work selflessly and creatively. Therefore, for the formation of effective motivational levers and incentives of the motivated work system requires a careful and comprehensive study of work values and motivational attitudes of employees.

With the help of the administration of the Ukrainian plant "STATE ENTERPRISE “KHARKIV MACHINE-BUILDING PLANT "FED” authors conducted a sociological survey at the branches of the plant in other cities of Ukraine in 2018-2019. The survey covered such important factors as satisfaction with the level of work organization, work performed, motives of work attractiveness, workplaces equipment, satisfaction with the work and salary, motives of work activity and connection of wages with the final work results.

Important factors are the level of work organization and the conformity of the performed work to spiritual requests. The level of satisfaction with the work organization at the enterprises of Ukraine is lower than at the enterprises of other countries.

\section{Results}

The existing organization of work does not fully respond to the display of employees' abilities and work with full dedication (Table 1), but with few exceptions, the majority of respondents noted satisfaction with the work performed (Table 2).

All measures to improve the organization of work should be aimed primarily at enhancing social and creative activity, independence in work. In a market economy, it is not enough to just follow job descriptions without initiative and independence.

Table 1

Level of work organization and its influence on the workers' skills and work impact (in \% of asked respondents)

\begin{tabular}{|c|c|c|c|c|c|}
\hline \multirow{2}{*}{$\begin{array}{l}\text { Level of work } \\
\text { organization }\end{array}$} & \multicolumn{5}{|c|}{ Ukrainian organizations } \\
\hline & $\begin{array}{c}\text { Lutsk repair plant } \\
\text { «Motor» }\end{array}$ & $\begin{array}{l}\text { «Motor-Sich» } \\
\text { (Zaporizhzhia) }\end{array}$ & $\begin{array}{c}\text { Pervomaisk car } \\
\text { plant }\end{array}$ & $\begin{array}{c}\text { Vovchansk } \\
\text { aggregate factory }\end{array}$ & $\begin{array}{c}\text { Kharkiv aggregate } \\
\text { design bureau }\end{array}$ \\
\hline Fully satisfy & 30 & 35 & 33 & 34 & 30 \\
\hline Not satisfying & 22 & 20 & 22 & 16 & 28 \\
\hline Not fully satisfying & 48 & 45 & 45 & 50 & 42 \\
\hline
\end{tabular}

Table 2

Level of workers' satisfaction by done work (in \% of asked respondents)

\begin{tabular}{cccccc}
\hline \multirow{2}{*}{ Work } & \multicolumn{4}{c}{ Ukrainian organizations } \\
\cline { 2 - 6 } & $\begin{array}{c}\text { Lutsk repair plant } \\
\text { «Motor» }\end{array}$ & $\begin{array}{c}\text { «Motor-Sich» } \\
\text { (Zaporizhzhia) }\end{array}$ & $\begin{array}{c}\text { Pervomaisk car } \\
\text { plant }\end{array}$ & $\begin{array}{c}\text { Vovchansk } \\
\text { aggregate factory }\end{array}$ & $\begin{array}{c}\text { Kharkiv aggregate } \\
\text { design bureau }\end{array}$ \\
\hline Interesting & 70 & 60 & 73 & 53 & 58 \\
Not interesting & 10 & 17 & 10 & 14 & 15 \\
Not fully interesting & 20 & 23 & 17 & 33 & 27
\end{tabular}

Therefore, requirements for employees and their qualities are increasing. From this point of view, interesting data about the motives for attractiveness in the work at Ukrainian enterprises (Table 3). 
Table 3

Motives of work attractiveness (ranks of motives) at Ukrainian organizations

\begin{tabular}{|c|c|c|c|c|c|}
\hline \multirow[b]{2}{*}{ Motives } & \multicolumn{5}{|c|}{ Ranks of motives } \\
\hline & $\begin{array}{l}\text { Lutsk repair } \\
\text { plant «Motor» }\end{array}$ & $\begin{array}{l}\text { «Motor-Sich» } \\
\text { (Zaporizhzhia) }\end{array}$ & $\begin{array}{c}\text { Pervomaisk } \\
\text { car plant }\end{array}$ & $\begin{array}{c}\text { Vovchansk } \\
\text { aggregate factory }\end{array}$ & $\begin{array}{c}\text { Kharkiv aggregate } \\
\text { design bureau }\end{array}$ \\
\hline $\begin{array}{l}\text { The opportunity to show their } \\
\text { creative knowledge, experience }\end{array}$ & 2 & 2 & 5 & 4 & 2 \\
\hline $\begin{array}{l}\text { Working team, working with } \\
\text { people }\end{array}$ & 1 & 1 & 6 & 1 & 3 \\
\hline $\begin{array}{l}\text { Opportunity to be always among } \\
\text { the team }\end{array}$ & 5 & 5 & 4 & 2 & 6 \\
\hline Work organization & 10 & 10 & $9-10$ & $9-10$ & 8 \\
\hline Independence at work & 3 & 4 & 2 & 3 & 4 \\
\hline Good salary & 6 & 9 & $9-10$ & 7 & 9 \\
\hline Opportunity to raise skills & $7-8$ & 7 & 3 & 6 & 5 \\
\hline Variety, complexity, novelty & 4 & 3 & 1 & 5 & 1 \\
\hline $\begin{array}{c}\text { Absence of elements of manual } \\
\text { labor }\end{array}$ & 9 & 6 & 7 & $9-10$ & 7 \\
\hline Nothing attracts & $7-8$ & 8 & 8 & 8 & 10 \\
\hline
\end{tabular}

Thus, despite the fact that employees are not satisfied with the organization of their work and wages, they do not consider these motives important, giving them 6-10 places. Among the first employees named such motives of attractiveness as: working staff, work with people, diversity, complexity, novelty, possibility of displaying their knowledge, experience, independence in work.

Satisfaction with the organization of work is also determined by the level of technical equipment of workplaces, which, according to the respondents, does not answer their queries (Table 4).

Table 4

Necessary workplaces equipment (in \% of asked respondents)

\begin{tabular}{ccccc}
\hline Ukrainian organizations & $\begin{array}{c}\text { All necessary } \\
\text { equipment }\end{array}$ & $\begin{array}{c}\text { Just the most } \\
\text { necessary }\end{array}$ & Not fully equipped & Not equipped enough \\
\hline Lutsk repair plant «Motor» & 25 & 29 & 33 & 13 \\
«Motor-Sich» (Zaporizhzhia)) & 24.3 & 29.8 & 35 & 38 \\
Pervomaisk car plant & 21 & 25 & 37 & 10.9 \\
Vovchansk aggregate factory & 22.5 & 27 & 30 & 13.5 \\
Kharkiv aggregate design & 27 & 32 & & 11
\end{tabular}

As can be seen, on average, only one in four jobs is equipped with all the necessary equipment, and almost half of those surveyed indicated that they were not sufficiently equipped. About $30 \%$ said they only had what they needed.

Satisfaction with the level of wage, nature and content of work is presented in Table 5.

With the exception of the Vovchansk plant, where there were no employees satisfied with their jobs and wages, other enterprises were satisfied with the above mentioned characteristics from $4.5 \%$ (Lutsk) to $24 \%$ (Kharkiv). However, the vast majority of respondents in the range of $28 \%$ (Kharkiv) to $93.4 \%$ (Vovchansk) are not satisfied with either their wages or their work.

It is already accustomed to the ideological attitudes of the past and to the stereotype that persuades workers to believe that work is primary and work motivation is secondary.

It seems that a person works for the sake of hard work. In fact, according to the results of the study, the circumstances are a little different. Studies of the past years [10, p. 113] and 
the researches conducted by the author give reason to believe that among the motivators of work activity, the first place is the salary. This motivator was put first by all employees of enterprises (Table 6).

Table 5

Satisfaction with the level of wage, nature and content of work

\begin{tabular}{cccccc}
\hline \multirow{2}{*}{ Answer } & \multicolumn{5}{c}{ Ukrainian organizations } \\
\cline { 2 - 6 } & $\begin{array}{c}\text { Lutsk repair plant } \\
\text { «Motor» }\end{array}$ & $\begin{array}{c}\text { «Motor-Sich» } \\
\text { (Zaporizhzhia) }\end{array}$ & $\begin{array}{c}\text { Pervomaisk car } \\
\text { plant }\end{array}$ & $\begin{array}{c}\text { Vovchansk } \\
\text { aggregate factory }\end{array}$ & $\begin{array}{c}\text { Kharkiv aggregate } \\
\text { design bureau }\end{array}$ \\
\hline Yes & 4.5 & 14.9 & 16.1 & - & 24 \\
No & 86.3 & 59.6 & 74.3 & 93.4 & 28 \\
Hard to answer & 9.2 & 25.5 & 9.6 & 6.6 & 48
\end{tabular}

Table 6

Work motives (in \%)

\begin{tabular}{cccccc}
\hline \multirow{2}{*}{$\begin{array}{c}\text { Work } \\
\text { characteristics }\end{array}$} & $\begin{array}{c}\text { Lutsk repair plant } \\
\text { «Motor» }\end{array}$ & $\begin{array}{c}\text { «Motor-Sich» } \\
\text { (Zaporizhzhia) }\end{array}$ & $\begin{array}{c}\text { Pervomaisk car } \\
\text { plant }\end{array}$ & $\begin{array}{c}\text { Vovchansk } \\
\text { aggregate factory }\end{array}$ & $\begin{array}{c}\text { Kharkiv aggregate } \\
\text { design bureau }\end{array}$ \\
\hline $\begin{array}{c}\text { Work is a mean of } \\
\text { earning money }\end{array}$ & 71.8 & 59.2 & 57.4 & 64 & 80.6 \\
Creative need & 6.6 & 4.5 & 2.1 & 16 & 12.9 \\
Desire to work & 21.6 & 36.3 & 40.5 & 20 & 6.5
\end{tabular}

The amplitude of employees' opinions about work as a means of earnings in all enterprises ranges from $57.4 \%$ at the Pervomaisk Plant to $80.6 \%$ at the Kharkiv Bureau. In second place, in terms of importance, work activity is motivated by the simple need to work.

The difference of opinion here is more significant from $6.5 \%$ (Kharkiv) to $40.5 \%$ (Pervomaisk). And only in third place is the motivator of creative necessity of labor activity from $2,1 \%$ (Pervomaisk) to $16 \%$ (Vovchansk).

A motivation system can be considered effective if every employee of the enterprise feels a direct dependence of his/her salary on the final results of individual or collective work. An important place is occupied by the organization of wages (forms and systems of remuneration, bonuses, different types of co-payments). If employees feel this connection, then it can be said that the remuneration system achieves its purpose and encourages them to work more effectively for the end result. The findings of this opinion on the relationship of wages with the final results of activity are reflected in Table 7.

Table 7

Relation of wages to final work results (in \%)

\begin{tabular}{cccccc}
\hline \multirow{2}{*}{ Answer } & \multicolumn{5}{c}{ Ukrainian organizations } \\
\cline { 2 - 6 } & $\begin{array}{c}\text { Lutsk repair plant } \\
\text { «Motor» }\end{array}$ & $\begin{array}{c}\text { «Motor-Sich» } \\
\text { (Zaporizhzhia) }\end{array}$ & $\begin{array}{c}\text { Pervomaisk car } \\
\text { plant }\end{array}$ & $\begin{array}{c}\text { Vovchansk } \\
\text { aggregate factory }\end{array}$ & $\begin{array}{c}\text { Kharkiv aggregate } \\
\text { design bureau }\end{array}$ \\
\hline Yes & 19.9 & 27.9 & 47.7 & 49.9 & 38.7 \\
No & 80.1 & 72.1 & 52.3 & 50.1 & 61.3
\end{tabular}

\section{Discussion}

It should be noted that the motivation systems that operate at the surveyed enterprises are ineffective, because the vast majority of respondents do not feel the connection of wag- 
es with the final results of work. Particularly noteworthy is the opinion of the employees of the motor factory "Motor", $80.1 \%$ of whom indicated the absence of such dependence, and "Motor-Sich" (72.1\%). They feel such dependence through the system of tariff rates and officials $49.9 \%$ of the employees of the Vovchansk plant, $47.7 \%$ of the Pervomaisk plant and $38.7 \%$ of the Kharkiv bureau.

In our view, strengthening of this dependence should be facilitated by a change in the procedure and procedure for setting tariff rates, salaries, taking into account qualifications, length of service and work results. An important factor in establishing a closer relationship between pay and performance should be a system of annual employee certification (as evidenced by the survey results, the system of performance appraisal, which operate in enterprises just formally operate).

According to the results of the sociological survey, the material motivation of the employees is far from perfect, because its impact on increasing the interest of employees in the results of the work remains minimal and does not contribute to the development of creative potential and business qualities.

The results of research by other scientists confirm the main results of our study, for example, research the problems in the mechanism of personnel management at "Tokmak Forging and Stamping Plant" PLC points out that the main reasons for dissatisfaction with the work of "TFSP" PLC are low wages, inefficient material and moral incentives, lack of interconnection. The connection between the results of work and its remuneration, insufficient opportunities for professional development, insignificant career prospects [14, p. 148].

In addition, numerous surveys of employees also indicate the inconsistency of the current state of wages in enterprises with the basic characteristics of a decent wage. According to a survey conducted by the Federation of Trade Unions of Ukraine among Ukrainian workers, it was found that only $27.7 \%$ of respondents are fully satisfied with the salary at the company where they work. The vast majority of employees (42\%) who took part in the survey, it does not suit, because it is very low $[15$, p. 38$]$.

\section{Conclusions}

In general, all surveyed enterprises revealed many deficiencies in the organization of work. For the most part, the work performed by employees does not meet their requirements, does not contribute to the development of abilities. First of all, according to the results of the survey, the manager should pay attention for creating a favorable atmosphere in the work team, to give employees the opportunity to show their creative knowledge and experience, independence in work. A very important step to increase employee satisfaction with their work is to optimize the level of wages, to link them with the end results of work, to have sufficient equipment for employees' work.

Thus, the system of work motivation in any enterprise can be effective only in the conditions of periodic, full questioning of employees about the existing shortcomings both in the organization, in payment, and in satisfaction of employees' needs. It depends only on the management of the company how faithfully the wishes of the employees will be fulfilled and, as a consequence, what will be the dedication to the enterprise and the level of motivation of the employees.

\section{References}

[1] Khaet, G. L., Eskov, A. L. (2000). Upravlenie motivaciei truda i optimizaciia ego sredy. Doneck: IEP NAN Ukrainy, 554.

[2] Abramov, V. M., Daniuk, V. M., Kolot, A. M. (1995). Motyvatsiia i stymuliuvannia pratsi v umovakh perekhodu do rynku. Odessa: OKFA, 96.

[3] Khaet, G. L., Eskov, A. L., Khaet, L. G., Medvedeva, O. A. et. al. (1999). Struktura motivacionnoi sfery cheloveka. Trudovaia tipologiia. Produktivnist, 3, 11-19.

[4] Eskov, A. L., Kuliichuk, V. I. (2003). Menedzhment motivacii truda stanochnikov. Doneck: NAN Ukrainy. In-t ekonomiki prom-sti, 160.

[5] Vereshchahyna, L. A., Karelyna, Y. M. (2002). Psykholohyia potrebnostei y motyvatsyia personala. Kharkiv: Yzd-vo Human. Tsentr, 152. 
[6] Mishurova, I. V., Kutelev, P. V. (2003). Upravlenie motivaciei personala. Moscow: IKC «MarT»; Rostov-on-Don: Izdat. centr «MarT», 224.

[7] Schekin, G. V. (1999). Kak effektivno upravliat liudmi: psikhologiia kadrovogo menedzhmenta. Kyiv: MAUP, 400.

[8] Kulynych, T. V. (2020). Motyvatsiia ta stymuliuvannia pratsi yak skladova menedzhmentu pidpryiemstva. Internauka, 2 (3 (83)), 31-36. Available at: https://www.inter-nauka.com/uploads/public/15819468321862.pdf Last accessed: 08.04.2020

[9] Bawa, M. A. (2017). Employee motivation and productivity: a review of literature and implications for management practice. International Journal of Economics, Commerce and Management, V (12), 662-673. Available at: http://ijecm.co.uk/wp-content/uploads/2017/12/51239.pdf Last accessed: 09.04.2020

[10] Sanyal, M. K., Biswas, S. B. (2014). Employee Motivation from Performance Appraisal Implications: Test of a Theory in the Software Industry in West Bengal (India). Procedia Economics and Finance, 11, 182-196. doi: http://doi.org/10.1016/s22125671(14)00187-7

[11] Lee, M. T., Raschke, R. L. (2016). Understanding employee motivation and organizational performance: Arguments for a set-theoretic approach. Journal of Innovation \& Knowledge, 1 (3), 162-169. doi: http://doi.org/10.1016/j.jik.2016.01.004

[12] Banerjee, A. (2015). Integrating Human Motivation in Service Productivity. Procedia Manufacturing, 3, 3591-3598. doi: http:// doi.org/10.1016/j.promfg.2015.07.726

[13] Zámečník, R. (2014). The Measurement of Employee Motivation by Using Multi-factor Statistical Analysis. Procedia - Social and Behavioral Sciences, 109, 851-857. doi: http://doi.org/10.1016/j.sbspro.2013.12.553

[14] Shliaha, O. V., Kariaka, K. I. (2014). Zastosuvannia motyvatsiinoho monitorynhu na promyslovomu pidpryiemstvi. Available at: http://www.zgia.zp.ua/gazeta/evzdia_8_146.pdf Last accessed: 29.05.2020

[15] Doronina, O. A. (2013). Upravlinnia zarobitnoiu platoiu na pidpryiemstvi v konteksti realizatsii kontseptsii hidnoi pratsi. Available at: http://ena.lp.edu.ua/bitstream/ntb/26186/1/6-35-40.pdf Last accessed: 30.05.2020 